\title{
Isolation and Characterisation of Diazotrophic Bacteria from Rhizosphere of different Rice Cultivars of South Assam, India
}

\author{
FOLGUNI LASKAR* and G.D.SHARMA \\ Department of Life Science and Bio-Informatics, Assam University, Silchar - 788 011, India. \\ Department of Life Sciences, Bilaspur University, Chattisgarh - 495 009, India. \\ DOI : http://dx.doi.org/10.12944/CWE.8.1.20
}

(Received: March 24, 2013; Accepted: April 14, 2013)

\begin{abstract}
Free living heterotrophic bacteria were isolated from the rhizosphere of 10 local and cultivated varieties of rice grown in Karimganj district of South Assam. Among the 25 isolates, 11 isolates withplant growth promoting activity were identified based on phenotypic and 16S rDNA sequence analysis. The strains were identified as Shingomonasa zotifigens, Pseudomonas putida, Stenotrophomonas maltophila, Acinetobacter radioresistance, Alkaligenes faecalis, Enterobacter cloaceae subsp. dissolvens, Pantoea agglomerans, Klebsiella pneumoneae, Achromobacter xyloxidans, Herbispirillum rubrisubalbicans and Herbispirillum sp. The efficient strains are isolated from the local varieties of rice plant. The isolate KR-23 (Sphingomonas azotifigens) was a novel bacteria reported for the first time as nitrogen fixing bacteria from India. The nitrogen fixing ability along with IAA production, ACC deaminase activity and P-solubilisation by the bacteria has shown their potential for plant-growth-promoting rhizobacteria. KR-6 (Stenotrophomon asmaltophila) and KR-7(Herbispirillum rubrisubalbicans) have been reported earlier as plant pathogens but they have shown a high potential for nitrogen fixing and auxin producing activity in the present study.
\end{abstract}

Key words: Nitrogen fixation; Plant growth promoting rhizobacteria; 16S rDNA sequence; Indole-3-acetic acid; ACC deaminase activity.

\section{INTRODUCTION}

Free living nitrogen fixing bacteria have been considered as an alternative for inorganic nitrogen fertiliser for promoting plant growth (Ladha and Reddy, 2000; Park et al., 2004). Inspite of the fact that a variety of nitrogen fixing bacteria have been isolated from the rhizosphere of various crops, interest in isolating more beneficial plant growth promoting bacteria has increased recently due to their potential use as bio fertiliser (Vessey, 2003). Cultivated rice (Oryzasativa) originated from species of wild rice and was domesticated several thousand years ago (Hoshikawa,1989; Oka,1988; Kennedy et al., 2001). Wild rice species are likely to harbour unique populations of nitrogen-fixing bacteria that differ from those in extensively bred modern varieties of cultivated rice (Hurek et al., 2000). Production of phytohormones (Tienet al., 1979; Haahtelaet al.,
1990) and competitive suppression of plant phytopathogens (Glick, 1995, Park et al., 2004) are the beneficial effects of these microbes on plant. The agricultural soil of South Assam experience heavy annual rainfall, resulting in leaching of nutrients causing economic loss to the farmers (Anonymous, 2007). The use of bio-fertilisers may be an alternative to the chemical fertiliser for achieving sustainable rice farming while improving productivity in rice-agro ecosystem.

The objective of the present study was to isolate, identify and molecular characterisation of diazotrophic bacteria from the rhizosphere of native local varieties of rice from different microhabitats of South Assam, India and characterise them for nitrogen fixation and plant growth promoting activities. 


\section{MATERIALS AND METHODS}

\section{Bacterial growth media}

Burk's $\mathrm{N}$-free medium comprising : $10 \mathrm{~g}$ glucose, $0.41 \mathrm{~g} \mathrm{KH}_{2} \mathrm{PO}_{4}, 0.52 \mathrm{~g} \mathrm{Na}_{2} \mathrm{SO}_{4}, 0.2 \mathrm{~g} \mathrm{CaCl}_{2}$, $0.1 \mathrm{~g} \mathrm{MgSO}_{4} .7 \mathrm{H}_{2} \mathrm{O}, 0.005 \mathrm{~g} \mathrm{FeSO}_{4} .7 \mathrm{H}_{2} \mathrm{O}, 0.0025 \mathrm{~g}$ $\mathrm{Na}_{2} \mathrm{MoO}_{4} \cdot 2 \mathrm{H}_{2} \mathrm{O}, 1.8 \mathrm{~g}$ agar (all per litre distilled water) for semi solid and $15 \mathrm{~g}$ agar for solid medium was used throughout the study (Wilson and Knight, 1952). The $\mathrm{pH}$ of the medium was adjusted to $7 \pm 0.1$ before autoclaving at $121^{\circ} \mathrm{C}$ for $15 \mathrm{mins}$

\section{Soil sample collection and isolation of diazotrophs}

Ten native rice cultivars grown under different microhabitats in Karimganj districts of South Assam were randomly selected. Riceplant were uprooted from a depth of $0-5 \mathrm{~cm}$ for rhizospheric soil sampling. The samples were then immediately placed in sterilized plastic packs and sealed brought to the laboratory and stored at a temperature of $4^{\circ} \mathrm{C}$. Ten grams of the rhizospheric soil sample was transferred to a $250 \mathrm{ml}$ of Erlenmeyer flask containing $90 \mathrm{ml}$ of sterile distilled water and shaken (120rpm) for $30 \mathrm{mins}$. Serial dilution was made and $0.1 \mathrm{ml}$ aliquots $\left(10^{3}-10^{5}\right)$ were spread on plates containing Burk's $\mathrm{N}$-free medium. The plates were incubated for 7 days at $30^{\circ} \mathrm{C}$. Morphologically different colonies appearing on the medium were isolated and sub-cultured for further analysis.

\section{Phenotypic characterisation of the bacterial isolates}

Physiological and biochemical characters of the bacterial isolates were examined according to the methods described in Bergey's Manual of Systematic Bacteriology (Holt et al., 1994). Colour, pigment, form, diameter, elevation, margin, surface, opacity and texture of the colonies of respective isolates were observed. Motility and morphology were examined with the help of phase contrast microscopy. The gram reaction was performed as per standard protocol. Plate assays were performed for determining the starch hydrolysis, carbon source utilisation of the isolates. MR-VP test, indole test, urea hydrolysis test were also performed.

\section{S rDNA gene amplification and sequencing} Genomic DNA was obtained by using standard bacterial procedure (Sambrook et al., 1989; Park et al.,2004). Extraction of the lysate was done two times with chloroform to remove residual phenol. The primers used for PCR amplification of the 16 s ribosomal DNA are 27F (5"-AGAGTTTGATC CTGGCTCAG-3") and 1492R (5"-TACGGTTACCT TGTTACGACTT-3") (Weisberg et al.,1999). Each PCR mixture $(50 \mu \mathrm{l})$ contained primers (at a concentration of 20pmol) a mixture of dNTP (Promega Co., Southampton, England) (at a concentration of $200 \mu \mathrm{M}$ ), Taq polymerase buffer and

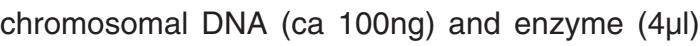
were added to the reaction mixture. The thermo cycling condition consisted of an initial denaturation step at $94^{\circ} \mathrm{C}$ for $4 \mathrm{~min}, 35$ amplification cycles of $94^{\circ} \mathrm{C}$ for $1 \mathrm{~min}, 58^{\circ} \mathrm{C}$ for $1 \mathrm{~min}$ and $72^{\circ} \mathrm{C}$ for $3 \mathrm{~min}$ and a final extension step of $72^{\circ} \mathrm{C}$ for $10 \mathrm{~min}$ with Gene-Amp PCR system (Perkin-Elmer Co., Norwalk, Conn.). PCR products were run and visualised on a $0.7 \%$ agarose gel. The $16 \mathrm{~S}$ rDNA nucleotide sequences was determined by PCR direct sequencing using ABI PRISM 310 Genetic Analyser (PE Applied Biosystems, Foster City, CA) and Big Dye Terminator cycle system (PE Applied Biosystems). Related sequences were obtained from Genebank Database, National Centre for Biotechnology Information(NCBI) using BLAST, Version 2 (Altschul et al., 1990; Park et al.,2004). The sequences were aligned and the consensus sequences was computed using Clustal W software. The evolutionary history was inferred using the Neighbor-Joining method (Saitou $\mathrm{N}$ et al., 1987) and the evolutionary distances were computed using the Maximum Composite Likelihood method (Kumar $S$ et al., 2004) MEGA version 5 (Kumar et al., 1993).

\section{Acetylene reduction assay (ARA)}

Nitrogenase activity of bacterial strains was determined in semisolid nitrogen free malate medium (by using acetylene reduction assay (ARA; HARDY et al. 1973). Pure bacterial colonies were inoculated on to NFM medium in McCartine vials of $10 \mathrm{ml}$ capacity and incubated at $28 \pm 2^{\circ} \mathrm{C}$ for $48 \mathrm{~h}$. Acetylene gas $(10 \% \mathrm{vol} / \mathrm{vol})$ was injected to the vials. After incubation for $16 \mathrm{~h}$ at $28 \pm 2{ }^{\circ} \mathrm{C}$, gas samples (100 il) were analyzed on a Hewlett Packard gas chromatograph (Model HP 6890, USA) using Porapak-N column and $\mathrm{H} 2$ flame ionization detector. After completion of ARA the cell were 
predigested by adding 10\% SDS and sonicated briefly. Protein concentration in the resulting mixture of suspension was determined by Lowry's method. (Lowry et al.,1951).

\section{Indole-3-acetic acid production}

IAA production by the isolates was determined by growing the isolates in Burk's medium supplemented with L-tryptophan $(100 \mathrm{mg} / \mathrm{l})$ at $30^{\circ} \mathrm{C}$. The supernatant of the culture fluid was obtained by centrifuging the stationary phase cultures at $10,000 \mathrm{rpm}$ for $15 \mathrm{~min}$ and the $\mathrm{pH}$ was adjusted to 2.8 with $1 \mathrm{~N} \mathrm{HCL}$. The auxins from the acidified cultures extracted with the equal volumes of ethyl acetate (Park et al., 2004; Tienet al., 1979) was evaporated to dryness and re-suspended in $4 \mathrm{ml}$ of ethanol. Analysis of the samples was done by HPLC (Water series 474, USA) using UV detector on a Nova-Pak 5-ODS C-18 column. Methanol: acetic acid: water (30:1:70 v/v/v) was used as mobile phase at a rate of $0.6 \mathrm{mlmin}^{-1}$ (Rasulet al., 1998). Pure indole-3-acetic acid (Sigma USA) was used as standard. The IAA of the samples was quantified by comparing the retention times, peak areas, and UV absorbance spectra with those of the standard using a Millenium 32 Login software with an interface (Waters, USA) attached with computer.

\section{Phosphorous solubilisation}

Test for P-solubilisation was done following Goldstein (1986). The appearance of clearing zone around bacterial colonies after $96 \mathrm{~h}$ of growth at $30^{\circ} \mathrm{C}$ was used as indicator for $\mathrm{P}$ solubilisation. Plates inoculated with heat killed cells served as control.

\section{ACC deaminase activity}

ACC deaminase activity was determined following the method described by Glick et al., 1995. For this $1 \mu \mathrm{l}$ of each LB pure bacterial culture was inoculated into agar plates containing NFb or NFbACC modified by addition of 1-aminocyclopropane1-carboxylate $\left(5.0 \mathrm{gl}^{-1}\right)$ as unique nitrogen source. Plates were incubated at $28^{\circ} \mathrm{C}$ and observed daily for colony formation for upto 4 days. Colonies were re-inoculated and incubated in the same experimental conditions. Newly colonies formed in $\mathrm{NFb}$ with addition of ACC were considered positive for ACC deaminase activity.

\section{Statistical analysis}

Results of the measurements were subjected to analysis of variance (ANOVA) using SAS package, Version 8.2 (SAS, 2001).

\section{RESULTS}

The isolation and identification of diverse groups of diazotrophs has paved the way to decrease the costs and use of inorganic $\mathrm{N}$-fertiliser as well as minimises the risk of pollution of agroecosystem from the application of chemical fertilisers. Previous researches on isolation of nitrogen fixing bacteria have revealed a broad diversity of diazotrophs associated with different crop rhizosphere (Vessey, 2003). Diverse free living or associative $\mathrm{N}_{2}$-fixing microorganisms (aerobes, facultative anaerobes, heterotrophs, phototrophs) grew in wetland rice fields and contributed to soil $\mathrm{N}$. The location, variety of rice plant, soil type and ARA, IAA activity and ACC deaminase activity of different isolates from rhizosphere soil has beenshown in Table 1. Total 25 free living nitrogen fixing bacterial isolates were isolated on Burk's nitrogen free media. The isolates were then purified and sub-cultured on solid nitrogen free medium.

The ability to reduce acetylene was an indicator of nitrogen fixing potential and was specific for monitoring functional nitrogen fixing potential (Andrade et al., 1997). Out of 25 isolates, 11 were selected for their efficiency in nitrogen fixing, having ARA activity, IAA activity and ACC deaminase activity. Among all the strains KR-23 exhibited highest nitrogenise activity (300 $\mathrm{nmolC}_{2} \mathrm{H}_{4} \mathrm{~h}^{-1} \mathrm{mg}^{-1}$ protein).

Biochemical characterisation of the strains showed that all the strains were gram -ive, motile rods and having varying metabolic activities. The biochemical characteristics of all the isolates are given in Table 2.

From 16S rDNA sequence analysis of the strains it was observed that ninety nine percent sequence identity was observed between the $16 \mathrm{~S}$ rDNA sequence of KR-4 with Pseudomonas putida; KR-23 and KR-5 with Spingomonas azotifigens; KR-6 with Stenotrophomonas maltophila; KR-16 with Herbispirillum sp. KR-7 with Herbispirillum 
Table 1: Plant source, isolate number, location and acetylene reduction assay of different isolates from rhizosphere of rice plant

\begin{tabular}{|c|c|c|c|c|c|}
\hline $\begin{array}{l}\text { Native } \\
\text { rice } \\
\text { cultivers }\end{array}$ & $\begin{array}{l}\text { Bacterial } \\
\text { Isolates }\end{array}$ & Microhabitats & $\begin{array}{c}\text { Nitrogenase activity } \\
\text { (ethylene/h/ } \\
\text { mg protein) }\end{array}$ & $\begin{array}{c}\text { IAA } \\
\text { activity } \\
(\mathrm{mg} / \mathrm{ml})\end{array}$ & $\begin{array}{c}\text { ACC } \\
\text { deaminase } \\
\text { activity }\end{array}$ \\
\hline \multirow[t]{4}{*}{ Ranjit } & $\mathrm{K} 1$ & Akbarpur & $19.85 \pm 2.35$ & - & - \\
\hline & K22 & Nilambajar & $42.83 \pm 3.45$ & - & - \\
\hline & K16 & Kanisail & $205 \pm 2.11$ & $1.22 \pm 1.09$ & + \\
\hline & $\mathrm{K} 2$ & Nilambajar & $11.43 \pm 3.45$ & - & - \\
\hline \multirow[t]{3}{*}{ Badah } & K18 & Ghoramara & $39.89 \pm 4.23$ & $1.04 \pm 1.22$ & + \\
\hline & K9 & Akbarpur & $32.11 \pm 3.22$ & $0.09 \pm 1.89$ & - \\
\hline & K3 & Kanisail & $89.12 \pm 4.22$ & - & - \\
\hline \multirow[t]{2}{*}{ Jaya } & K4 & Laxmibajar & $280 \pm 2.11$ & $2.23 \pm 2.21$ & + \\
\hline & K5 & Chorgola & $300.21 \pm 3.45$ & $1.45 \pm 1.22$ & + \\
\hline \multirow[t]{4}{*}{ Biroin } & K7 & Akbarpur & $180 \pm 3.45$ & $1.01 \pm 1.21$ & + \\
\hline & K11 & Ghoramara & $56.77 \pm 2.11$ & - & - \\
\hline & K12 & Asimganj & $90.89 \pm 3.24$ & $0.01 \pm 1.01$ & - \\
\hline & K15 & Patharkandi & $106.6 \pm 4.54$ & $0.89 \pm 1.45$ & + \\
\hline \multirow[t]{3}{*}{ Kalijeera } & $\mathrm{K} 17$ & Patharkandi & $45.67 \pm 2.44$ & - & - \\
\hline & K6 & Asimganj & $150 \pm 2.32$ & $0.98 \pm 1.25$ & + \\
\hline & K8 & Chorgola & $115.66 \pm 2.56$ & $1.09 \pm 2.21$ & + \\
\hline \multirow[t]{3}{*}{ Latma } & K23 & Ghoramara & $290.22 \pm 3.45$ & $1.45 \pm 1.22$ & + \\
\hline & K34 & Kanisail & $210 \pm 2.34$ & $1.87 \pm 1.50$ & + \\
\hline & K33 & Nilambajar & $140.77 \pm 3.23$ & $0.03 \pm 1.22$ & - \\
\hline \multirow[t]{4}{*}{ Latiali } & K76 & Akbarpur & $112 \pm 1.23$ & $0.11 \pm 1.23$ & - \\
\hline & K28 & Chorgola & $68.88 \pm 2.55$ & $0.89 \pm 1.22$ & + \\
\hline & K20 & Laxmibajar & $54.32 \pm 3.23$ & $0.98 \pm 1.44$ & + \\
\hline & K61 & Nilambajar & $75.77 \pm 3.11$ & - & - \\
\hline \multirow[t]{2}{*}{ Pankaj } & K81 & Chorgola & $67.76 \pm 2.13$ & - & - \\
\hline & K19 & Asimganj & $56.66 \pm 3.24$ & - & - \\
\hline
\end{tabular}

Each value represents mean of three replicates. The difference between the results is significant at a level of $5 \%$ significance. $(\mathrm{P} \leq 0.05)$.

Table 2: Biochemical characteristics of diazotrophic isolates

\begin{tabular}{lccccccccccc}
\hline Biochemical tests & K23 & K4 & K6 & K16 & K7 & K28 & K18 & K8 & K34 & K15 & K20 \\
\hline Indole test & - & - & - & - & - & - & - & - & - & - & - \\
Voges-Proskauer test & - & - & - & - & - & + & + & - & - & + & - \\
Gas production from glucose & + & - & + & - & - & + & + & + & + & + & - \\
Starch hydrolysis & + & - & - & - & - & - & - & - & - & - & - \\
Urea hydrolysis & - & & - & + & + & + & + & - & - & - & - \\
Nitrate reduction & - & - & + & - & - & - & + & - & + & + & + \\
Catalase test & + & + & + & + & + & + & + & + & + & + & + \\
Oxidase test & + & + & - & + & + & & & + & - & - & - \\
Gelatin hydrolysis & - & - & + & - & - & + & + & - & - & - & - \\
\hline
\end{tabular}




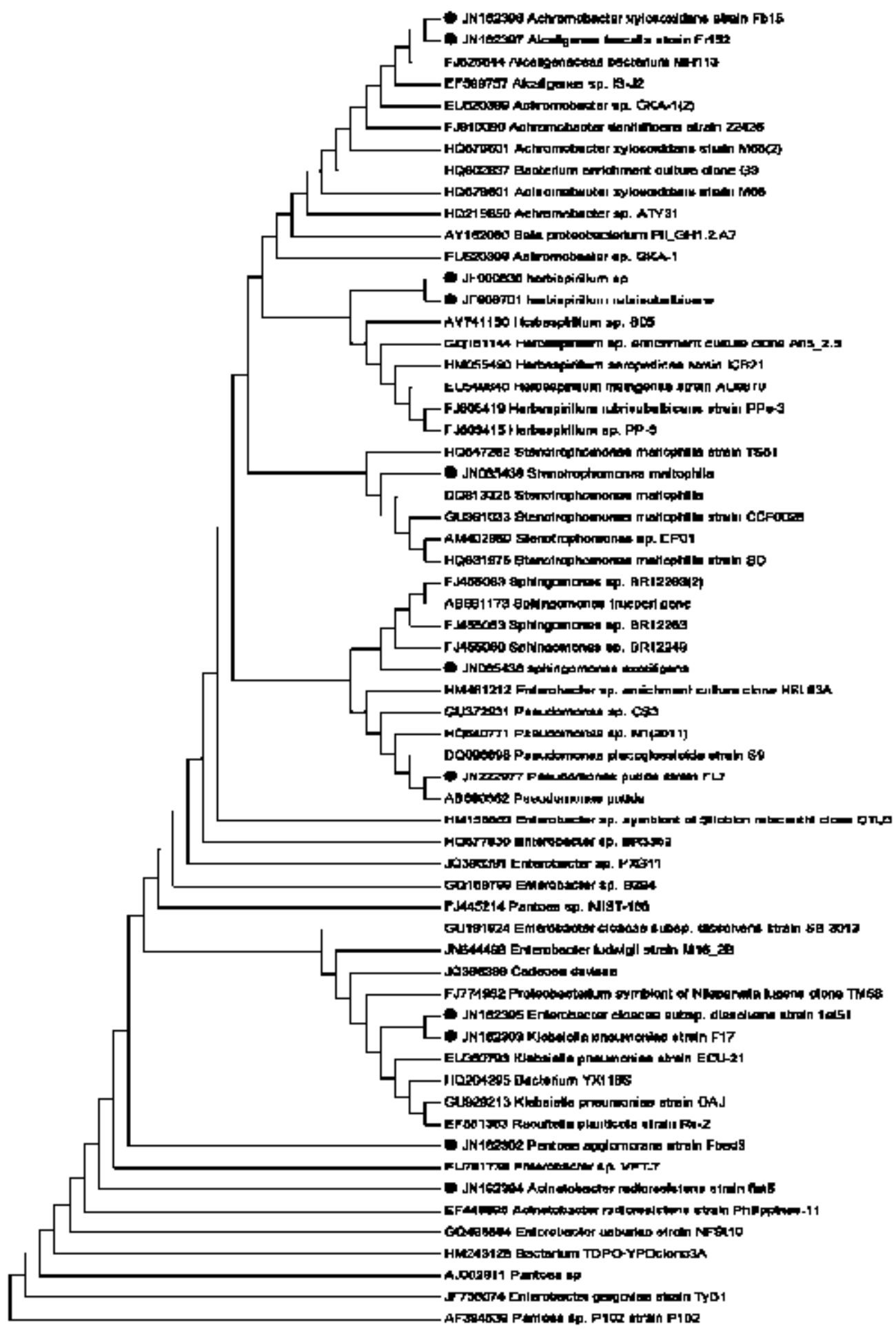

Fig. 1: Phylogenetic tree derived from analysis of the 16S rDNA sequences of Strain KR-23, KR-4, KR-6, KR-16 and KR-7 and related sequences obtained from NCBI. Scale bar, 0.02 substitutions per nucleotide position 
rubrisubalbicans, KR-28 with Klebsiella pneumonia, K15 with Pantoe aagglomerans, KR34 with Acinetobacter radioresistance, KR-18 with Enterobacter cloaceae sub $\mathrm{sp}$ dissolvens, KR-8 with Alcaligenes faecalis and KR-20 with Achromobacter xyloxidans. Isolation of all the above bacteria were already reported from different crops by many workers (Bhromsiriet al., 2010; Sa et al. 2009; Uretaet al., 1995; Gholamiet al., 2009; Xieet al., 2006). A phenogram reflecting the relationship among the strains and candidate sequences of various nitrogen fixing strains obtained from database of NCBI has been presented in Fig 1. The sequences obtained were submitted to NCBI with accession numbers KR-4: JN222977, KR-23: JN085438, KR-5: JN085437, KR-6: JN085439, KR16:JF990839, KR-7:JF906701, KR-28:JN162393, KR-8: JN162397, KR-20: JN162396, KR-15: JN162392; KR-34: JN162392, KR-18: JN162395.

\section{DISCUSSION}

Plant growth promoting rhizobacteria offer an environmentally sustainable approach to increase crop production and health. The IAA production and ACC deaminase activity of the microbes help in the stimulation of growth and pathogenesis of the plants. In this study all the 11 strains produced considerable amount of IAA and are also capable of ACC deaminase activity which can be comparable to the earlier studies on various bacteria by different workers (Malik et al., 1997; Sucksstorff and Berg, 2003; Park et al., 2004; Xieet al., 2006). The amount of ARA and IAA activity and the capability of ACC deaminase activity is shown in Table 1. Among all the isolates Sphingomonas azotifigens, Pseudomonas putida, Pantoeaagglo merans, Enterobacter cloaceae sub sp. dissolvens,
Klebsiella pneumoneae and Herbispirillum sp can solubilise phosphorous.

This study reports the isolation and characterisation of the strains of S.azotifigens, $S$. maltophila, P. putida, Herbispirillum sp., $H$. rubrisubalbicans, P.agglomerans, A.xyloxidans, $A$ radioresistance, $A$. faecalis, E. cloaceae subsp. dissolvens and K. Pneumoneaefrom the inorganic fertiliser rich rhizosphere soil of rice agro-ecosystem of South Assam confirming their nitrogen fixing potential.

Sphingomonas azotifigens is reported from the rice fields of South Assam for the first time in India in our study. All the 11 isolates are capable of IAA production and ACC deaminaseactivity, among them some are capable of P-solubilisation. The isolates Pseudomonas putida, Sphingomonas azotifigens, Herbispirillum sp and has been regarded as PGPR in earlier studies (Gholami, 2009; Park et al., 2004; Baldaniet al., 2009), but Stenotrophomonasmaltophila and Herbispirillum rubrisubalbicans, as producer of IAA and capable of ACC deaminase is also reported first time in our study. These two bacteria are reported as pathogenic and endophytes in many earlier study(Reinhardt et al.,2008;Denton et al.1999; Hale et al., 1972; Gillis et al., 1990). An increased knowledge of the role of these isolates in plant growth promotion under pot culture as well as field condition is required to prove them as plant growth promoting rhizobacteria.

\section{ACKNOWLEDGEMENTS}

The authors are grateful to the Head, Department of Life Science, Assam University (Silchar), India for providing laboratory facile.

\section{REFERENCE}

1. AltschulS.F., Gish W., Miller W., Myers E.W. and Lipman D.J., J. Mol. Biol., 215: 403 (1990).

2. Andrade G., Esteban E., Velascol L., Maria J.L. and Bedmar E.J., Plant Soil 197: 19 (1997).
3. Baldani I.J. and Baldani L.V.,Anais Da Acad. Brasiliera De Ciencias Sci., 77: 549 (2005).

4. Bhromsiri C. andBhromsiriA ., Thail J. Agric. Sci., 43(4): 239 (2010).

5. Cheng-HuiXie and Yokota A., International Journal of Systematic and Evolutionary 
Microbiology, 56: 889 (2006).

6. Denton M. and Kerr K.G.,Clin.Microbiol. Rev. 11: 57 (1998).

7. Reinhardt E. L., Ramos P.L.,Manfio G.P., Barbosa H.R.,Pavan C. and Carlos A. Moreira-Filho C.A., Brazilian Journal of Microbiology, 39: 414 (2008).

8. GholamiA., Shahsavani S. and Nezarat S., World Academy of Science, Engineering and Technology 49 (2009).

9. Gillis M., Dobereiner J., Pot B., Goor M., Falsen E., Hoste B., Reinhold B. and Kersters K. In M. Polsinelli, R. Materassi, and M. Vincenzini (ed.), Nitrogen fixation. Kluwer Academic Publisher, Dordrecht, The Netherlands. 293 (1990).

10. Glick B.R., Can. J. Microbiol. 41: 109 (1995).

11. Goldstein A.H.,Am. J. Alter. Agric., 1: 51 (1986).

12. Gyaneshwar P., James E.K., Mathan N., Reddy P.M, Reinhold B., Hurek and Ladha. J. Bacteriol.,183: 2634 (2001).

13. Haahtela K., Konkoo R., Laakso T., Williams P.H. and Korhonem T.K., Mol. Plant Microbe Interact., 3: 358 (1990).

14. Hale C. N. and Wilke J.P., J. Agric. Res., 15448 (1972).

15. Hardy R.W.F., Holsten R.D. and Jackson E.K., Plant Physiol., 43: 118 (1968).

16. Holt J.G., Kreig N.R., Sneath P.H.A., Staley J.T., Williams S.T., Williams and Wilkins, Baltimore, USA (1994).

17. Hoshikawa, K. Anthesis, Science of the Rice Plant, VolumeOne. Morphology, 339. Tokyo: Food and Agriculture Policy Research Center (1993).

18. Kennedy I. R., Choudhury A.T.M.A. and Kecskés M.L., Journal of Soil Biology and
Biochemistry, 36(8): 1229 (2004).

19. Ladha, J.K. and Reddy, P.M., The quest for nitrogen fixation in rice. Proceedings of the Third Working Group Meeting on Assessing Opportunities for Nitrogen Fixation in Rice, 9-12 Aug. 1999, IRRI, Los Banos, Laguna, Philippines, 354 (2000).

20. Lowry H.O., Rosebrough N.J., Farr A.G. and Randall R.J., J. Biol. Chem., 193: 265 (1951).

21. Park M., Kim C., Yang J., Lee H., Shin W, Kim S. and Sa T., Microbiological Research 160: 127 (2005).

22. Oka, H.I..Origin of Cultivated Rice. Tokyo:Japanese Scientific Societies Press (1988).

23. Rasul G., Mirza M.S., Latif F. and Malik K.A., Kluwer Academic Publishers, Dordrecht, The Netherlands, 25 (1998).

24. SAS, Institute Inc.,SAS user's guide, Version 8.2. SAS Institute Inc., Cary, North Carolina, USA (2001).

25. Saitou N. andNei M., Mol. Biol. Evol., 4: 406 (1987).

26. Shahi S.K., Rai A.K., Tyagi M.B., Sinha R.P. and Kumar A., African Journal of Biotechnology, 10(42): 8296 (2011).

27. Suckstorffl., Berg G., J. Appl. Microbiol., 95: 656 (2003).

28. Tien T.M., Gaskins M.H. andHubbel D.H., Appl. Environ. Microbiol., 37, 1016 (1979).

29. Ureta A., Alvarez B., Ramon A., Vera M A. and Martinez-Drets G., Plant Soil 172, 271 (1995).

30. Vessey J.K., Plant Soil 255: 571 (2003).

31. Weisburg W.G., Barns S.M., Pelletier D.A.and Lane D.J., J. Bacteriol. 173: 697 (1991).

32. Wilson P.W. andKnight S.C.,Burguess, Minneapolis, USA, 49 (1952). 